\section{HONOURS, AWARDS, APPOINTMENTS}

\section{Double glory for loannis}

loannis Levisianos, a third year orthodontics student at the UCL Eastman Dental Institute and Specialist Registrar at the Eastman Dental Hospital, has been awarded the celebrated J K Williams Medal of the Faculty of Dental Surgery, Royal College of Surgeons of England. The award is made annually to the candidate who secures the highest marks in the BiCollegiate Membership in Orthodontics examination.

Ioannis also received the extremely competitive Houston Research Poster Prize at the 87th European Orthodontic Society Congress in Istanbul in June this year. The award is for the best research poster of unpublished research on a topic of orthodontic interest.

New Dean for King's College London Dental Institute Dr Dianne Rekow has been appointed new Dean to King's College London's Dental Institute. Dr Rekow is president of the International Association for Dental Research (IADR) an an internationally renowned authority on the performance of new materials and products for use in aesthetic and restorative dentistry. Dr Rekow succeeds Professor Nairn Wilson, who is due to retire at the end of this year.

\section{Olympic torchbearer nomination}

Sixty-two years after winning a bronze medal in athletics in the Empire Games (the former name for the Commonwealth Games), 91-year-old Vice President of the BDA Benevolent Fund, Tony Chivers, has been nominated by the Fund to be a Torchbearer in the 2012 Olympic Games. Tony has been successful in making it through to the regional selection stage.

\section{Gold for Cockermouth}

St Helen's Dental Practice in Cockermouth, Cumbria, has won the prestigious Investors in People Gold standard. This is the only dental practice in the North West to achieve the gold award and it puts the practice in the top 1.5\% of over 21,000 UK businesses that have achieved the Investors in People Standard.

\section{Best student presentation}

At the grand old age of 51 (her words), dentist Julia Beaumont has won an award for the best student presentation at the annual conference of the British Association for Biological and Anthropological Osteoarchaeology (BABAO) held in Edinburgh this month. Julia is studying part-time for a PhD in the Department of Archaeological Sciences, Bradford University, supervised by Dr Janet Montgomery, and also practises dentistry in Littleborough alongside her husband.

\section{New Chair for Warwick}

The Dental Directory is funding a new Chair in Dentistry at the University of Warwick, to celebrate its 40 years in business. The new Chair will focus on primary care and will be appointed later this year.

\title{
TWO HUNDRED YEARS OF AMERICAN DENTAL HISTORY ON DISPLAY
}

Dental artifacts from the 1800 s to the present were on display to the public for six days only at the University of Nebraska Medical Center College of Dentistry in September in Lincoln, Nebraska.

Thousands of dental artifacts were on display in one of the largest collections in the United States. Curator and oral biology professor Dr Stan Harn has spent over 30 years collecting remnants of dental history. The museum featured six period dental practices from the 1850 s to the 1930 s, more than 35 dental cabinets including some with intricate Victorian design, dental chairs dating from 1855 to 1880 , a collection of tooth extraction instruments such as a metal hook known as a turnkey, X-ray machines with exposed wiring and foot-powered drills.

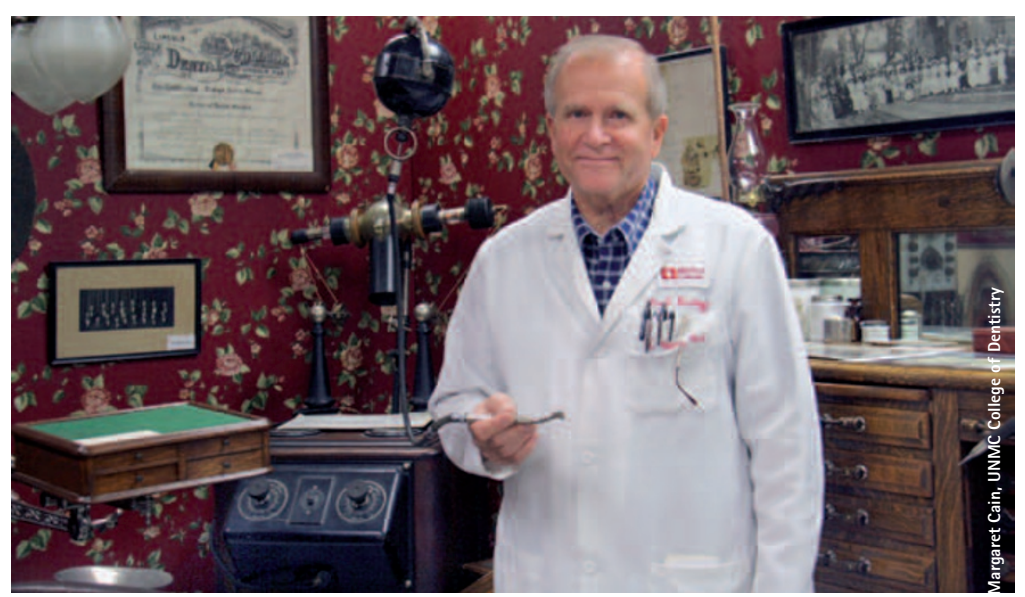

Dr Stan Harn of the University of Nebraska Medical Center College of Dentistry holding a wall mounted drill in a period dental office from the early 1900 s

\section{UNPREDICTABLE MARKET REVEALED IN PRACTICE SALES}

The sale value of the average dental practice has dropped from

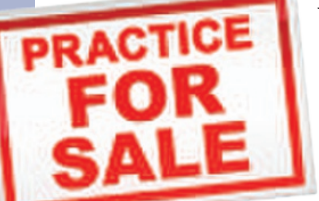
$98 \%$ of turnover in the quarter ending April 2011 to $90 \%$ of turnover in the most recent quarter ending 31 July 2011 - according to figures collected by the National Association of Specialist Dental

Accountants \& Lawyers (NASDAL).

The goodwill

survey conducted by NASDAL reflects a significant number of dental practice sales in any quarter.

'Some very high value deals for large NHS practices are being done with the large chains which has an upward effect on the average,' said Alan Suggett, a partner in unw LLP in Newcastle who carries out the survey. 'However, the market is far less predictable now than historically.

Ray Goodman, Chairman of the NASDAL Lawyers Group, said that it was too early to tell whether the slight softening in goodwill values was a trend or another fluctuation: 'Goodwill appeared quite settled at 100\% but now the figures are lower and there seems to be more uncertainty.' 